\title{
1 The Realism of Assumptions Does Matter: Why Keynes-Minsky Theory Must Replace Efficient Market Theory as the Guide to Financial Regulation Policy
}

\author{
From Oxford Handbook of the Political Economy of \\ Financial Crises. G. Epstein and M. Wolfson editors. \\ Oxford University Press, 2013
}

\subsection{INTRODUCTION}

In the aftermath of the financial collapse in the US that began in 1929, it was almost universally believed that unregulated financial markets are inherently unstable, vulnerable to fraud and manipulation by insiders, and capable of triggering deep economic crises and political and social unrest. These economic and political events were compatible with the theories of endogenous financial instability created by John Maynard Keynes and augmented by Hyman Minsky. To protect the country from financial instability, the US government created a strict regulatory system that worked effectively through the 1960s. Economic and financial turbulence in the 1970s and early 1980s led to both a paradigm and a policy regime shift. The neoclassical theory of "efficient" or "perfect" financial markets and new classical macro theory (which assumes that markets always generate full employment) replaced the theoretical visions of Keynes and Minsky. ${ }^{1}$ The government, influenced by the belief that efficient financial market theory was sanctioned by economic "science," radically deregulated US financial markets after 1980.

Most financial economists argue that lightly regulated financial markets allow individual and institutional investors to achieve the maximum return for a given risk level and choose the amount of risk that is optimal for them. Such markets also allocate scarce resources to their most productive uses, making the real sector of the economy itself more efficient. It would have been much harder to enact radical deregulation if the core of the economics profession had opposed 
efficient market theory and supported tight regulation, as they did in the 1950s and 1960s. ${ }^{2}$ In the words of Nobel Laureate Joseph Stiglitz:

The economics profession bears more than a little culpability [for the global financial and economic crisis]. It provided the models that gave comfort to regulators that markets could be self-regulated; that they were efficient and self-correcting. The efficient markets hypothesis - the notion that market prices fully revealed all the relevant information - ruled the day. Today, not only is our economy in a shambles but so too is the economic paradigm that predominated in the years before the crisis - or at least it should be (Financial Times, "Needed: a new economic paradigm," August 19, 2010).

Francis Fukuyama, an advisor to Ronald Reagan and the second George Bush, commented on the symbiotic relation between large financial firms and financial economists that he believes contributed to the professions' support of the efficient financial market hypothesis:

Wall Street seduced the economics profession not through overt corruption, but by aligning the incentives of economists with its own. It very easy for academic economists to move from universities to central banks to hedge funds - a tightly knit world in which everyone shared the same views about the self-regulating and beneficial effects of open capital markets. The alliance was enormously profitable for everyone: The academics got big consulting fees, and Wall Street got legitimacy. And it has kept the system going despite the enormous policy failures it has generated, not to exclude the recent crisis (quoted in Skomarovsky 2011). ${ }^{3}$

Efficient market theory was not universally supported by the profession's elite. There were respected financial economists whose criticism of mainstream theory appeared in first-rank economics journals. Some used assumptions of principalagent conflict, asymmetric information and incomplete contracts to undermine to some unspecified degree the conclusion of market efficiency. Others relied on behavioral financial theory to demonstrate that various forms of psychologicallygrounded investor "irrationality" can help explain disappointing empirical tests of market efficiency. But these theories are not intended to be substitutes for the vision incorporated in neoclassical financial theory. Rather, they are meant to be amendments to it that do not challenge its dominant position in the profession. "The behavioral finance literature ... simply adopts the neoclassical view with biases added (e.g., overshooting, undershooting, framing, etc.") (Findlay and Williams 2008-2009, p. 224). Camerer and Lowenstein insist that behavioral finance does not seek "a wholesale rejection of the neoclassical approach to economics based on utility maximization, equilibrium and efficiency" (2004, p. 1). Matthew Rabin, a star in the behaviorist camp, argues that their research program is "not only built on the premise that mainstream economic methods are great, but also that most mainstream economic assumptions are great" (2002, p. 658, emphasis in original). And, like problems of child or spouse abuse, 
these theoretical disputes were primarily kept within the family of mainstream financial economists. Thus, their existence did not erode the public's belief that the profession strongly supported deregulation.

The theory of efficient and optimal financial markets appears to nonbelievers to be a rather absurd theory because it is based on a long list of grossly unrealistic assumptions that bear little relationship to the real-world financial system. Moreover, empirical tests of the theory are disappointing. This raises two interesting questions: How could a theory built on an assumption set that bears no resemblance to real-world markets and has very weak empirical support become so widely accepted by financial economists? And why do financial economists reject the much more realistic theories associated with Keynes and Minsky that can explain events such as the recent crisis?

An important part of the answer to this question resides in the peculiar methodology used by most of the economics profession - the theory of positivism as explained and defended by Milton Friedman in his famous 1953 essay "The Methodology of Positive Economics."4 This methodology is examined in section 2 , where its claim that the realism of assumptions has no relevance in judging the validity of a theory is assessed and found wanting. Section 3 critically evaluates empirical tests used to defend the theory of optimal financial markets. Section 4 compares the canonical neoclassical capital asset pricing model with the theory of financial markets associated with Keynes and Minsky (KM), and argues that $\mathrm{KM}$ theory is a superior theory and therefore a much better guide to regulation policy precisely because it is based on realistic assumptions. Section 5 presents three examples of how the unrealistic assumptions of mainstream theory misled regulators and investors in the recent crisis. The last section offers concluding observations.

\subsection{FRIEDMAN'S POSITIVISM AND THE DOMINANCE OF THE THEORY OF OPTIMAL FINANCIAL MARKETS}

The theory of ideal financial markets has two component parts. The first is the assumption that financial markets have perfect informational efficiency; this is the "efficient market" hypothesis or EMH per se. The second is the assumption that market prices are optimal equilibrium prices set by rational utilitymaximizing agents who have perfect information about the future cash flows associated with all securities.

The EMH asserts that all information relevant to the correct pricing of securities is utilized in the pricing process. As Eugene Fama, one of the creators of efficient market theory, put it: "I take the market efficiency hypothesis to be the simple statement that security prices fully reflect all available information" 
(1991,p. 1575). Fama observed that "models of market equilibrium start with the presumption that markets are efficient" (Federal Reserve Bank of Minneapolis 2007, emphasis added). Thus, efficiency is neither a derived nor an observable nor a directly testable property of financial markets. It is an assumption required to construct optimal asset pricing models that conclude that risk and return are appropriately priced.

The EMH raises two important questions: what is the relevant information set that is available to investors; and what does it mean to say that this information is "fully reflected" in security prices. With respect to the first question, neoclassical financial markets theory assumes that the information set available to investors consists of the correct expectation of the probability distributions of future cash flows associated with each security. In other words, the theory is built on the assumption that investors, through some miraculous but unspecified process, gain perfect knowledge of the future..$^{5}$ Through a peculiar twist in language, these expectations are called "rational" expectations, even though it would seem to be the height of irrationality to assume that that anyone can know the future. However, as discussed below, the assumption that all relevant information is used to price securities is not uniquely associated with neoclassical theory. In a Keynesian world in which no one can know the future, sensible agents would also use all information they deemed relevant to form their expectations, though they would have no reason to believe that their expectations were assuredly correct.

An answer to the second question requires the specification of a pricing model or theory that can be used to convert cash-flow expectations into security prices. Mainstream financial market theory posits that all agents use "rational" expectations as input into one of the canonical models of optimal security pricing, such as the capital asset pricing model (CAPM) or the options pricing model. The model uses rational expectations to generate prices that are optimal in that they that accurately reflect the risk and return associated with all securities. The perfect financial markets paradigm that has sustained the deregulation movement thus consists of the joint hypothesis that the EMH and a canonical theory of optimal pricing together explain how markets actually generate security prices.

There are two serious problems with the mainstream theory of optimal financial security pricing. The first is methodological and deals with the relation between assumptions and conclusions or derived hypotheses. The second relates to the empirical evidence used to support the theory.

Few economists think about methodology, but the methodological foundation of neoclassical economics is Milton Friedman's (1953) version of “positivism." Positivism asserts two important theses. First, in evaluating the validity or usefulness of a theory, neither the extent to which the assumption set of a theory incorporates all the core elements of the phenomenon under investigation, nor the institutional or behavioral or empirical realism of the assumptions adopted 
matter. The "relation between the significance of a theory and the "realism" of its "assumptions" is almost the opposite of that suggested by [critics of positivism]. Truly important and significant hypotheses will be found to have "assumptions" that are wildly inaccurate descriptive representations of reality ..." (Friedman 1953 , p. 14). Second, it is impossible to determine whether one assumption is more realistic than another. A theory "cannot be tested by comparing its "assumptions" directly with "reality." Indeed, there is no meaningful way in which this can be done" (p. 41). The only legitimate test of a theory, then, is whether its derived hypotheses can be used to make predictions that are consistent with relevant data: "The only relevant test of the validity of a hypothesis is comparison of its predictions with experience" (Friedman 1953, p. 9). Since prediction testing of necessity involves ceteris paribus assumptions, in practice the profession relies on econometric hypothesis-testing with past data.

Why would an academic profession sanction the use of theories based on crassly unrealistic assumptions? It is not an intuitively attractive idea. One suspects that the underlying reason is: economists are, in the main, committed to the defense of propositions that cannot be generated by models based on realistic assumptions. For example, a long string of unrealistic assumptions are necessary to generate the desired conclusion that unregulated financial markets perform optimally. Consider the comment by William Sharpe in a seminal article on the CAPM that helped win him the Nobel Prize:

Needless to say, [the assumptions of the model] are highly restrictive and undoubtedly unrealistic assumptions. However, since the proper test of a theory is not the realism of its assumptions, but the acceptability of its implications, and since these assumptions imply equilibrium conditions which form a major part of classical financial doctrine, it is far from clear that this formulation should be rejected..." (1964, p. 434, emphasis added).

Of course, classical financial doctrine insists that competitive financial markets are efficient.

In 1970 Sharpe acknowledged that if just one of the many unrealistic assumptions used to create the CAPM - that agents could borrow without limit at the risk-free interest rate - is rejected, "the theory is in shambles." He argued that the inclusion of "such aspects of reality are likely to be disastrous in terms of the usefulness of the resulting theory" (quoted in Smith 2010, p. 82-83). The method used here clearly is to adopt whatever assumptions set is required to generate the desired efficient-market conclusion.

Milton Friedman was not only an economist; he was an energetic conservative political activist as well. His positivist methodological made it possible for conservative economists to use an absurd set of assumptions that no one would accept as a reasonable description of real-world capitalism to generate wide-spread acceptance of the proposition that unregulated capitalism is an ideal 
system. Realistic assumptions lead to theories that show both the strengths but also the myriad dangers and failures of unregulated capitalism contained in the historical record. But positivism made possible a "scientific" defense of the proposition that capitalism has no dangers and failures. In other words, Friedman's positivism insulates flawed theories of capitalism that cannot explain or predict the actual behavior of capitalism from effective criticism.

There are numerous problems with Friedman's methodology, which has little support outside the economics profession. ${ }^{6}$ We mention two. First, if very unrealistic or patently false assumptions are adopted, as they often are, and impeccable logic is applied to deduce hypotheses from them, these hypotheses cannot - as a matter of logic - be an accurate reflection of reality. It was quite an accomplishment for positivism to triumph in spite of its denial of this proposition.

Second, by insisting that the only way to evaluate the extent to which a theory corresponds with reality is through econometric tests of its derived hypotheses, positivism places a stronger burden on the use of econometrics than it can possibly bear. Consider just two problems. The first is that in the age of high-powered computers, one can literally run millions of econometrics tests on a hypothesis until one or more of these tests deliver an acceptable result. Statistical tests of significance used to assess the realism of derived hypotheses have little meaning in this environment and opportunities for "data mining" are unlimited. Virtually any hypothesis will be found to be statistically significant if enough regressions are run.

Another problem is that all hypothesis tests combine theoretical propositions with empirical proxies for unobservable variables. Neoclassical theory per se has no testable propositions. It essentially argues that, in whatever context, agents will optimize. The properties of all general functions - production functions, utility functions, and so forth - must be specified in order to generate testable propositions. These properties are not an inherent part of the theory. Take the case of hypotheses in which unobservable expectations are important. A proxy for expectations must be selected before appropriate econometric tests can be conducted. The econometrics test is thus a joint hypothesis combining elements of theory with ad hoc assumptions about expectation formation not specified in or related to the theory. If the joint hypothesis is rejected, this does not mean the theory is "wrong" - and conversely. It could be that the theory is "right," but the ad hoc assumptions are not - and conversely. In the philosophy of science this is referred to as the Duhem-Quine thesis, which says that it is impossible to adequately test a theoretical proposition in isolation from assumptions not specified within the core theory.

Because of these and other problems, it is extremely difficult to demonstrate solely on the basis of econometric tests that one theory is consistent with reality while another is not. This is a fatal flaw in Friedman's methodology because 
it rejects all tests of validity other than prediction. It also helps explain why conflicting theories can co-exist. It is therefore of the utmost importance that economists use all relevant information in theory testing, including not only econometrics, but especially the degree of realism and completeness of the theory's assumption set and the ability of the theory to explain historical dynamic processes - such as the recent global crisis - endogenously.

The proposition that crudely unrealistic assumptions are not inferior to realistic assumptions in theory construction must be distinguished from the more reasonable proposition that some degree of abstraction - or approximation of reality - is necessary in theory building. The methodological debate, therefore, is not about whether some degree of abstraction is necessary, but rather whether or not we should favor theories whose assumptions are not excessively and unnecessarily at odds with the reality we wish to theorize.

Positivists claim that it is not possible to distinguish realistic from unrealistic assumptions, but this is not persuasive. Consider the assumption of "rational" expectations - the belief by rational agents that they have true knowledge of the future. This is clearly absurd. ${ }^{7}$ No sane economist believes anyone can know with certainty the true stochastic distribution of future cash flows. Yet the rationality of expectations is widely accepted because positivism sanctions the use of unrealistic assumptions. Economists can assess the realism of the assumption set through institutional and historical studies, survey research, experiments, insights from psychology and sociology, and basic fact checking. This is hardly a new or an original idea. Robert Solow stated that "we have no choice but to take seriously our own direct observations of the way economic institutions work ..." (1988, p. 311). Tony Lawson argued for devoting "more resources into learning about the institutional behaviours, norms, conventions - or, more generally, rule systems - that are produced and reproduced by people in the various spheres of activity" (1985, p. 925). Robert Shiller suggested that "we must base further modeling efforts on observation and human behavior and on the popular models that inform that behavior" (1992, p. 435). Keynes insisted that "Our conclusions must be based upon the actual observation of markets and business psychology" (1973, p. 149).

There is a superior method available to analyze the nature of financial markets and other important theoretical issues. Rather than searching for an assumption set that can demonstrate that financial markets are efficient, economists should construct a set of realistic assumptions about financial markets and ask: What hypotheses about the behavior of financial markets can be derived from these assumptions? This theory could then be evaluated using all feasible methods, from historical studies to econometrics. This is the method associated with the work of Keynes and Minsky.

When it comes to methodology, Keynes is the anti-Friedman. Keynes argued that useful theories can only be generated by realistic assumptions. Indeed, his 
most important methodological criticism of orthodox macro theory was that it is based on unrealistic assumptions and therefore must come to unrealistic conclusions. In the concluding chapter of The General Theory he wrote:

Our criticism of the accepted classical theory of economics has consisted not so much in finding logical flaws in its analysis as in pointing out that its tacit assumptions are seldom or never satisfied, with the result that it cannot solve the economic problems of the actual world (1973, p. 378, emphasis added).

In the Preface to The General Theory Keynes said that the objective of the book is to persuade economists to "to re-examine critically certain of their basic assumptions" (1973, p. xxi). The conclusions of classical theory are wrong, he said, because "the postulates of the classical theory are applicable to a special case only," and "the characteristics of the special case assumed by classical theory happen not to be those of the economic society in which we actually live" $(1973$, p. 3). His clear message is that the realism of assumptions does matter: conclusions generated from unrealistic assumptions cannot possibly be correct.

Perhaps the clearest example of this message is his powerful attack, in The General Theory and in his 1937 defense of that book in the Quarterly Journal of Economics, on the mainstream assumption that agents know the correct probability distribution of future states of the economy. This assumption is a necessary condition for the construction of theories of perfect markets. He argued to the contrary that the future is unknowable or uncertain: "there is no scientific basis on which to form any calculable probability whatever ... We simply do not know" (1937, p. 214). The replacement of the assumption of knowable "risk" with the assumption of "uncertainty" - "we simply do not know" - revolutionized our understanding of the nature of financial markets.

\subsection{TESTING THE THEORY OF OPTIMAL UNREGULATED FINANCIAL MARKETS: FRIEDMAN'S POSITIVISM IN ACTION}

There is a large and conflicted literature on econometrics tests of the EMH itself. The main problem here is that tests require both the assumption of EMH and the specification of a model of equilibrium asset pricing. This makes it impossible to test the EMH by itself. It "is not empirically testable unless some equilibrium model of security returns is specified" (Beaver 1981, p. 28). As Fama put it:

We can only test whether information is properly reflected in prices in the context of a pricing model that defines the meaning of "properly." As a result, when we find anomalous evidence on the behavior of returns, the way it should be split between 
market inefficiency or a bad model of market equilibrium is ambiguous. ... It is a disappointing fact that, because of the joint-hypothesis problem, precise inferences about the market efficiency are likely to remain impossible (Fama 1991, p. 1576, emphasis added).

The CAPM is a canonical neoclassical theory in which agents trading in perfectly competitive markets use the complete and correct information contained in rational expectations of future cash flows to determine equilibrium security prices. It assumes the EMH is correct. The assumptions used lead inevitably to the conclusion that security prices are optimal because they were chosen to do just that. The CAPM demonstrates that all investors will hold the same portfolio of securities - the "market portfolio" - that includes all risky securities available plus a risk-free security. It is optimal because asset diversification takes advantage of imperfect covariance among security cash-flows to minimize risk at a given return. Less risk-averse investors hold proportionately less of the risk-free security and borrow to increase their holdings of the market portfolio, raising expected return while increasing portfolio risk.

It is important to understand that the CAPM is a theory of optimal relative price determination. It has nothing to say about the behavior of security price levels, which are the focus of concern in theories of financial market instability and in regulation debates. The key question for those trying to understand the behavior of financial markets is not whether GM's stock price is correctly in line with GE's, but why security prices move in boom-bust patterns. Larry Summers famously ridiculed the much ballyhooed main finding of the CAPM: "They have shown that two-quart bottles of ketchup [risk-adjusted return] invariably sell for twice as much as one-quart bottles of ketchup ..." (Summers 1985, p 634).

It is not difficult to test the derived hypotheses of the CAPM because it has a specific assumption about the way in which risk affects the relative prices of securities, and a clear definition of risk - the covariance of a security with the market portfolio. ${ }^{8}$ However, empirical tests of the CAPM have, for the most part, been disappointing to supporters of neoclassical theory. Econometrics tests thus raise serious questions about whether financial markets get even relative security prices "right." In a widely discussed survey of empirical tests of hypotheses derived from the CAPM, Fama and French (2004) come to a stunning conclusion: "despite its seductive simplicity, the CAPM's empirical problems probably invalidate its use in applications" (p. 44). The tenets of positivism suggest that economists should not accept the CAPM because its derived hypotheses do not have convincing econometric confirmation.

However, rather than accept this conclusion, neoclassical financial economists instead argued that the CAPM must have failed econometric tests because it defined risk too narrowly. This led to a wealth of econometric studies of arbitrage pricing models that add numerous and sundry additional variables to the risk measure of the CAPM. Since, in contrast to the CAPM, arbitrage pricing 
theory does not define what these other risk factors should be, the entire effort appears to be data mining - searching for any plausible variables that might lead to acceptable econometric results. There is, in principle, no limit to the extent of this search.

There are other widely discussed tests of the theory of optimal financial markets. "Event studies" are designed to show that when new information about a company's profit prospects appears in the press, its stock price quickly moves in the appropriate direction. These tests are much less impressive than proponents suggest. ${ }^{9}$ First, there is selection bias in deciding what kinds of new information to use in the tests. Events whose effect on stock prices is inconsistent with the desired conclusion may be excluded from testing. Second, event studies do not test for the size of price movements, only their direction. They therefore cannot be used as evidence that stock prices are in equilibrium as required by canonical neoclassical models. Third, virtually any theory of financial markets would pass these event tests. For example, KM theory also predicts that new information showing that profits were higher than expected would cause stock prices to rise. Event tests may provide evidence that market prices react quickly to news, but they are not evidence that the neoclassical theory of security pricing is correct. This is a general weakness of all econometric tests of canonical models such as the CAPM. They never test whether these theories are superior or inferior to alternative theories. In a review of the methodology of modern financial market theory, Findley and Williams argued that "in an empirical-positivist sense, at best [neoclassical financial market theory's] implications could not be rejected by the available evidence - a test which many opposing models could also pass" (1985, p. 1).

Another important test is whether or not professional investors generally out-perform financial markets, which is presumed to be equivalent to asking whether they out-perform individual investors. Canonical models assume that everyone has the same information and uses the same model to translate that information into security prices. Most empirical studies do find that professionals cannot generate greater returns (at the same risk) than amateurs, which is taken as confirmation that these assumptions are correct. Important financial economists seem to rely on this test more than anything else in their defense of market efficiency. Burton Malkiel stated: "For me, the strongest evidence suggesting that markets are generally quite efficient is that professionals do not beat the market" (Malkiel 2005, p. 2). ${ }^{10}$

However, even if the pros don't beat the market, it would not necessarily mean that everyone had access to the same information at the same time and used it in the same model. In the current era professional investors are the market, at least to a first approximation. They hold most of the securities and do almost all the trading. So it would be hard for them to outperform themselves. ${ }^{11}$ Moreover, tens of millions of individuals pay professional investors large sums of money to manage their portfolios. If professionals cannot manage portfolios better than these 
individuals, then this army of individual investors must be irrational. But irrational agents are prohibited by assumption in canonical neoclassical financial theory; it is a rational-agent based theory. So the finding that pros don't beat the market implies that a fundamental assumption of neoclassical financial theory is incorrect.

All these tests reflect the assumption that markets are always in equilibrium. The canonical models contain a "no arbitrage" assumption; you can't find arbitrage opportunities in equilibrium pricing models. But the narrative in which the model is embedded contains an explanation of why prices remain in equilibrium. If there are excess profits to be made without increasing risk because markets are not in equilibrium, professional arbitrageurs will take advantage of this opportunity, thereby quickly eliminating out-of-equilibrium profit. ${ }^{12}$ For example, hedge funds are supposed to excel at relative-price arbitrage. So the justification of the "no arbitrage" assumption of the CAPM is a posited belief in quick and efficient arbitrage when prices are out of equilibrium. This raises the question: Why aren't out-of-equilibrium dynamics incorporated in the CAPM? The answer is that modeling disequilibrium processes can destroy the desired conclusion that security prices are always optimal, as can be seen in debates over "noise trading" and "rational bubbles." Ironically, the ubiquitous arbitrage story also implies that many professionals do outperform the market. ${ }^{13}$

Given that mainstream methodology rejects the use of the realism of assumptions as an acceptable criterion for testing the validity of a theory, econometric tests must carry the entire burden of defense of optimal financial market theory. Since the assumptions used to construct the theory and derive its hypotheses are strikingly unrealistic, one would assume that empirical tests would have to pass with flying colors in order to sustain support for the theory and its general vision of financial markets. Yet, as in the case of CAPM, mediocre to disappointing empirical tests have not led to rejection of its underlying theoretical vision - which is essential to the defense of radical deregulation - as it should have under the positivist method. Rather, it has led to ever-changing models of market efficiency. It would seem that the vision captured by the CAPM is deeply anchored in an ideological commitment to free markets rather than in disinterested scientific study, and that the profession's commitment to positivism per se is only skin deep.

Finally, it is interesting to understand what some important professional defenders of financial market efficiency and optimality think about the relation between their theory and the nature of real-world security price levels. Burton Malkiel said the following:

What I do not argue is that market pricing is always perfect. After the fact, we know that markets have made egregious mistakes, as I think occurred during the recent internet "bubble." Nor do I deny that psychological factors influence security prices. But I am convinced that Benjamin Graham (1965) was correct in suggesting that while the stock market in the short run may be a voting machine, in the long run it is a weighing mechanism. True value will win in the end (2003,pp. 5-6, emphasis added). 
This is an astounding statement. In Malkiel's opinion, markets generate "egregious" pricing errors much of the time and psychological factors strongly influence stock prices, something ruled out by assumption in mainstream models. If markets badly misprice securities much of the time, real-sector resources are badly allocated much of the time. How inefficient! Nevertheless, he tells us we should be comforted by the belief that in the long run, security prices will be forced into proper balance with the ability of firms to generate profit. In this context, the term "long-run" can only mean at brief periods between booms and busts. Ironically, this belief is also embedded in the financial market theories of Keynes, Minsky and Marx. These theorists argue that security prices are inherently prone to substantial cyclical and secular volatility. Selfreinforcing bubbles inevitably occur from time to time; it is crises and panics that bring security prices back into temporary equilibrium with cash-flows. Busts are the markets "long-run" equilibrator. Of course, this balance is soon broken by the next bubble or crash. This is a vision in fundamental conflict with efficient market theory, which implies that security prices are always in harmony with cash-flows, yet Malkiel seems to agree with its conclusion.

Fischer Black, who helped create the options pricing model, made the following observation about absolute pricing efficiency in real-world financial markets.

We might define an efficient market as one in which price is within a factor of 2 of value; i.e., the price is more than half of value and less than twice value. By this definition, I think almost all markets efficient almost all the time. "Almost all" means at least 90 percent (Mehrling 2005, p. 236).

It is curious, to say the least, that such prominent supporters of the neoclassical theory of optimal financial markets believe that real-world security price levels are likely to be much higher or much lower than their "correct" values much of the time, and that booms and busts are common. Given this belief, they should have been opponents of radical deregulation.

\subsection{THE REALISM OF ASSUMPTIONS DOES MATTER: WHY THE KEYNES-MINSKY THEORY OF FINANCIAL MARKETS IS SUPERIOR TO MAINSTREAM THEORIES OF PERFECT MARKETS}

Consider the following assumptions used to construct the CAPM. Note that assumptions 2 and 3 reflect the fact that this is a model of static equilibrium with no dynamic processes and, therefore, no endogenous source of movement. 
1. Agents are risk-averse.

2. The degree of risk-aversion embodied in the utility function is exogenous to the model; agents do not become less risk-averse in the boom and more risk-averse in a panic because the theory only considers equilibria.

3. Expectations are exogenous. Agents do not become more optimistic in a boom and more pessimistic in a collapse.

4. Expectations are homogenous - there is no disagreement about future cash-flows among agents.

5. Since this is an equilibrium model with identical information sets, there is no trading in the model.

6. Expectations are correct or "rational" - the statistical distributions of future cash-flows are known with certainty. ${ }^{14}$

7. The expected cash-flows from the real sector are exogenous: nothing that happens within financial markets affects real-sector cash-flows in the model. ${ }^{15}$

8. Future cash-flow expectations are embodied in normal or Gaussian statistical distributions.

9. Since prices are always in equilibrium, liquidity is perfect; securities can always be sold (without cost) at their equilibrium value.

10. There is a risk-free security - like a Treasury bill.

11. Agents can borrow or lend without limit at the risk-free rate of interest.

12. No one can default.

13. There are no financial institutions in the model, only agents holding nonintermediated portfolios.

With the possible exception of the assumptions that investors are risk-averse and that the shortest-term Treasury bills are relatively riskless, this assumption set is a severe distortion of, rather than approximation to, reality. These assumptions were chosen because they are necessary and sufficient conditions for the conclusion that unregulated financial markets are optimal. A profession working with a reasonable methodology and a different ideology would have concluded that since the hypothesis that markets are optimal cannot be generated except by an absurdly unrealistic assumption set, the hypothesis is quite likely to be wrong.

Consider the following assumptions typically used in KM financial theory. Though they are abstractions from reality, they are reasonable approximations to it. This theory emphasizes endogenous dynamic processes. Assumption 1, the assertion that the future is inherently unknowable or uncertain, is a cornerstone of Keynes's macro theory as well as of his theory of financial markets. This assumption set generates a realistic theory of financial market dynamics as described in the rest of this section. 
1. The future is inherently unknowable. The world is characterized by uncertainty rather than calculable risk.

2. Expectations are endogenous and pro-cyclical. They become more optimistic in booms, more pessimistic in downturns, and wildly unstable in panics.

3. The degree of agent risk aversion is endogenous. Agents become less riskaverse in a bubble and more risk-averse in a downturn.

4. Agents are heterogeneous: they have different expectations, different degrees of risk aversion, and different portfolios. Agent heterogeneity is the main reason why there is massive daily and hourly trading on security markets. ${ }^{16}$

5. Financial market decisions affect real-sector outcomes and conversely in an interactive, dynamic and path-dependent process. Future cash flows are changed by agents' financial decisions.

6. There is no stable financial market equilibrium, though there are periods of relative stasis. Financial market centers of gravity are always being altered by endogenous change in expectations, risk aversion, and the condition of balance sheets, as well as by the creation and spread of real and financial innovations.

7. The degree of liquidity changes over time. There is excessive liquidity in the boom that pushes security prices to unsustainable levels, but liquidity evaporates in a crisis, making the crisis worse.

8. Agents cannot borrow without limit at a risk free interest rate. Credit is cheap and widely available in a bubble, which accelerates the speed of security price appreciation. However, when the bubble ends, credit evaporates and interest rates spike.

9. Defaults (and therefore counter-party risk) exist and are important. Defaults are highly counter-cyclical. Fear of default is a major source of downward price pressure in a collapse.

10. Financial institutions strongly affect the performance of financial markets. They are complex agents whose incentives, information sets, objectives and constraints differ from individual agents. ${ }^{17}$

The economic outcomes we observe over time are generated by a system of ever-changing agents, agent preferences, expectations, risk-aversion, innovations, and economic, political, and social institutions. Thus, the mechanisms that generate future outcomes cannot possibly be known in the present. Consider financial innovation. It has qualitatively changed the nature of financial markets in recent decades, but future innovations by their very nature cannot be known today. Indeed, some future changes are not only unknowable, but unimaginable. Thus, real-world agents must make decisions today, such as the capital investment decision and the portfolio composition decision, whose outcomes depend 
on future states of the economy that they cannot possibly know. The best agents can do is base their decisions on fallible expectations of some kind. These fallible expectations guide agent choice today and thereby influence the future trajectory of the economy. "What is imagined for a coming period must, in an ultimate sense, help to shape what will, ex post, emerge as the ultimate facts of that period" (Shackle 1992, p. 440).

The assumption of uncertainty raises the interesting question of what it means for agents to be rational. In neoclassical theory, agents are provided with complete and correct information about the future which they can use to make assuredly optimal decisions. This is the definition of rationality in neoclassical theory - given complete and correct information, agents do the optimization math correctly. But what if agents at best have information about the future they know to be incorrect and incomplete? (Strictly speaking, there can be no knowledge of the future.) How can they make rational decisions? Neoclassical theory has nothing to say about this question because it has assumed it out of existence. However, the main challenge facing the theory of agent choice is not to understand why fully informed agents act irrationally (though they may do so), but rather to understand how sensible agents make decisions under conditions of uncertainty or un-knowledge. Crotty (1994) provides a detailed Keynesian answer to the question of sensible agent choice in uncertain conditions.

Since agents are aware that they do not know the future, they can never have complete confidence that their expectations will be correct. This means that their decisions will be affected both by their forecasts and the degree of confidence they have in the usefulness or validity or reliability or truth-content of these forecasts - "on how highly we rate the likelihood of our best forecast turning out quite wrong" (Keynes 1973, p. 148). "Confidence" is a psychological and potentially unstable variable.

In KM theory both expectation and confidence formation are endogenous, changing with economic conditions. Agents have no choice but to use heuristics or conventions to forecast the future path of security prices and try to estimate their potential volatility or riskiness. Security price expectations are formed through extrapolation from the relevant past - unless there are strong reasons not to do so. Amromin and Sharpe analyze data on consumer financial market expectations to demonstrate that the description of the Keynesian process of conventional expectation formation is the way investors in fact behave. "In forming expectations of future returns, household investors appear to extrapolate from recent-years' realized returns.... [E]xpected returns appear to be procycylical" (Amromin and Sharpe 2009, p. 28).

The longer conventionally-determined expectations lead to decisions that generate satisfactory outcomes, as they do in booms, the greater the confidence that agents place in them. When a financial boom lasts for some time, agents 
begin to project its continuance. Given optimistic expectations of future prices, buying securities previously seen as risky will seem like a reasonable decision. As the boom proceeds and optimistic expectations are shown to be justified, buying securities with borrowed money will also seem reasonable. This drives the financial boom forward, raising leverage while raining capital gains on investors. The heaviest rain falls on the most aggressive investors, which leads most agents to believe either that risk is objectively low or that risk-taking brings much higher rewards than it used to. Risk-assessment and risk-preference are thus endogenous. When risky behavior is being highly rewarded, fear of risk declines and conversely.

Since agents are heterogeneous, trading is active. In the early stages of a boom, expectations may differ widely among agents. Bulls will buy securities from bears. But as optimism and confidence spread in the boom, bears turn bullish, and the merely optimistic begin to sell to the super-optimistic or least risk-averse.

Liquidity rises endogenously in a boom; eventually almost anyone can sell securities for more than they paid for them. Leverage rises as well because both borrowers and lenders come to believe that leverage is not as risky as it used to be. In recent cycles, the perverse compensation system used by key financial institutions rationally induced agents to use excessive leverage to boost their bonuses. Interest rates remain low through much of the boom, and credit is available even to agents previously considered to be bad credit risks.

There is a crucial feedback loop joining the real and financial sectors missing in efficient financial market theories. Rising security prices in the boom increase the value of individual and institutional agents' assets and net worth. This increases the amount of debt they believe they can safely hold and thus increases their borrowing power just as conventional definitions of adequate safety margins become less stringent. Rising use of credit to buy securities leads to yet higher prices, which in turn lead to more optimistic expectations held with increasing confidence, and higher wealth that can be used as collateral in leveraged security purchases. Meanwhile, rising consumer and business wealth and easy and cheap credit lead to increased consumption and investment spending. This raises aggregate demand, income, employment and profit, which in turn lead to higher actual and expected future cash flows that raise security prices.

Since every long-term financial boom is accompanied by the widespread belief that we have entered a "new era" in which the forces that ended all previous booms are no longer operative, the current boom eventually comes to be seen as permanent. A near-universal belief develops that high yields previously achievable only by accepting high risk can now be gained safely. ${ }^{18}$

As Keynes and Minsky stress, market ebullience cannot go on forever. As a boom matures, the economy becomes, in Minsky's famous phrase, "financially 
fragile." At some point, the economy becomes unable to generate the cash flows needed to sustain euphoria-inflated financial asset prices. Profits eventually decline and household income growth slows, leading to falling investment and sluggish consumption. As aggregate demand growth slows and unemployment rises, agents discover that their expectations were too optimistic and that security prices are too high relative to expected future cash flows. Expectations will be revised downward, confidence in the accuracy of forecasts will ebb, and security prices will begin to fall. Falling asset prices will cause a reverse wealth effect on consumption spending. In a typical downturn, falling home prices play an important role in the decline of household wealth. In the recent crisis, they were the central force in the process.

As financial institutions retrench in the face of rising risk, interest rates rise and defaults - assumed out of existence in the CAPM - jump. Fear of higher default rates will cause interest rates to rise further and credit for riskier agents to be eliminated. Risk aversion will increase. The rising leverage that drove the boom will now be reversed. As the price of at-risk securities falls, collateral-calls from lenders will be issued to all who bought now-shaky securities on credit. This will lead to the "forced sale" of these securities, which will accelerate their rate of price decline. As the market for suspect securities collapses, borrowers will be forced to sell "sound" securities, which will spread the crisis across markets. The CAPM assumes that liquidity is perfect and costless, but in a financial downturn few agents want to buy suspect financial assets, so they can only be sold at fire-sale prices. Watching their own asset values and their capital shrink, financial institutions will be less willing to loan to corporations, households or each other. In the mid-2000s, intra-financial-market debt was bloated and bank balance sheets and off-balance-sheet entities were loaded with excessively risky and nontransparent mortgage-related loans. This caused frightened banks to stop lending to each other when the boom ended, which helped turn the financial downturn into a panic.

Both the causes of the recent financial boom and the destructive downward dynamics of the subsequent collapse can be explained by KM theory because its assumption set adequately reflects the forces that drive financial markets. On the other hand, the assumption set used to construct canonical neoclassical financial and macro models makes such endogenous instability impossible. If the economics profession had rejected Friedman's positivism and built its core financial models on the realistic assumption used in KM theory, it would have been much harder for supporters of radical deregulation to have achieved their objective. 


\subsection{THREE EXAMPLES OF HOW THE ASSUMPTION SET USED IN THE NEOCLASSICAL MODEL PROFOUNDLY MISREPRESENTED THE DANGERS IN FINANCIAL MARKETS TO REGULATORS AND MARKET PARTICIPANTS}

\section{a) The Assumption that the Future is Characterized by Knowable "Risk" Rather Than Keynesian "Uncertainty" Allowed Banks to Become Dangerously Risky with their Regulators' Blessing}

Mainstream financial theory assumes that financial products and institutions are perfectly transparent. This is a precondition for efficient pricing. In fact, deregulation and financial innovation made the portfolios of the giant bank conglomerates that are at the center of the global financial system so complex that it became impossible for anyone to make a reliable estimate of their risk. In 1998 the Bank for International Settlements sanctioned the idea that regulators, who were now incapable of assessing the riskiness of large banks, should shift responsibility for setting limits on giant banks' risk to the banks themselves, who might be better informed. Banks were allowed to manage their own risk through a statistical exercise known as Value at Risk (VAR). They were, in effect, permitted to set their own capital requirements. Not surprisingly, they used this freedom to minimize them.

VAR is an estimate of the highest possible loss in the value of a portfolio of financial assets and liabilities over a fixed time interval with a specific statistical confidence level. Mimicking the CAPM and options pricing models, VAR models assume that the probability distribution of future security prices is predetermined and knowable - they are characterized by risk rather than uncertainty. They also assume that expectations can be adequately represented by a normal distribution. "All the models in the financial economics edifice assume a normal distribution" (Smith 2010, p. 79).

There are three fundamental flaws in this mode of risk assessment. First, a VAR calculation uses historical data to forecast future financial market performance, typically data from the past year or less. If this calculation is done in the midst of a boom, the data will reflect the "perfect calm" of the period - corporate profits will be high as will capital gains on securities, while interest rates, defaults and asset price volatility will be low. The possibility of the outbreak of crisis will not be considered because there are no crises in the data base. VAR analysis implicitly assumes this ideal environment is permanent. Thus, the risk associated with boom-induced high leverage and excessively optimistic expectations will be severely under-estimated. VAR's rosy risk-estimates allowed banks to hold dangerously low capital cushions 
and therefore enabled them to use extra leverage to continue to add risky securities to their portfolio. However, even if the data were extended to cover crises in past decades, growth and innovation would have changed the system so substantially that there would be little likelihood that the future would resemble the past extrapolated.

Second, while VAR models assume that security price movements conform to the normal distribution used in canonical financial models, in fact they follow a distribution in which the preponderance of observations are normal, but on occasion observations far from the mean appear - the well-known fat tail phenomenon. The standard exercise calculates VAR under negative conditions likely to occur only 5 percent of the time. In a normal distribution the likelihood that an observation several standard deviations beyond a 95 percent confidence interval will occur is infinitesimal. ${ }^{19}$ Yet tail events inevitably occur from time to time. The use of normal distributions allowed banks to assume that serious future crises were impossible. Thus, VAR risk estimates let banks minimize required capital and maximize leverage and lending capacity. This maximized profits and bonuses in the boom even as it sowed the seeds of a future crisis.

Third, the asset-price correlation matrix is a key determinant of measured VAR. The lower the correlation among security prices, the lower the portfolio's risk. VAR models assume that asset prices are jointly normally distributed and that future asset price correlations will be identical to those of the recent past. However, in crises most prices fall together as all investors run for liquidity and safety, creating a high positive correlation and dangerously high risk unaccounted for in VAR calculations.

\section{b) Core Neoclassical Models Assume that Leverage is not Dangerous. Belief in these Models Contributed to a Cavalier Attitude towards Debt}

The canonical models of optimal financial markets assume that leverage is never dangerous because fully-informed agents rationally choose an optimal debt position. In fact, under radical deregulation debt had risen to systemically dangerous levels by 2007.

From the mid 1990s until the onset of the crisis, economic growth was largely driven by rising household borrowing, the stimulus to consumption provided first by a booming stock market and, later, by an enormous increase in housing prices augmented by an explosion in home equity loans. In 1981 household debt was 48 percent of GDP, while in 2007 it was 100 percent. This meant that if job or wage growth slowed, the ability of households to sustain heavy debt loads would be compromised. It also meant that if interest rates rose or credit tightened, or if stock or housing prices declined, consumption spending and aggregate demand would decelerate, threatening job and wage growth. The economy had become extremely financially fragile. 
Financial firms were also excessively indebted; financial sector debt rose from 22 percent of GDP in 1981 to 117 percent in late 2008. The spectacular leverage and financial fragility of key financial sectors along with the gross overvaluation of the securities they held made a severe financial crisis almost inevitable. Excessive household debt and boom-augmented household wealth ensured that the real-sector fallout from a financial sector crisis would be severe, but this threat was hidden by neoclassical fairy tales about market efficiency.

It is estimated that half of the spectacular rise in investment banking return on equity in the four years ending in mid-2007 was attributable not to clever investment strategies or even to super-heated boom conditions, but simply to higher leverage with higher risk (Financial Times, "Worst period for investment banking in 30 years," April 2, 2008). Moreover, about half the debt of the big investment banks consisted of overnight borrowing that would evaporate in a crisis. Commercial banks appeared to be adequately capitalized during the boom, but only because a high percent of their assets - for some more than half - was kept off-balance-sheet, and the prices of all their assets were inflated by the bubble. In fact, banks were dangerously leveraged. When the crisis hit, the value of these assets, and therefore of bank capital, plummeted, causing a frantic global search for new capital, a spike in interest rates and a tightening of credit standards. The initial decline in security prices triggered a de-leveraging process in financial markets in which liquidity disappeared. Asset price declines led to margin calls, which led to forced assets sales and more margin calls in a dangerous downward spiral.

The shrinking availability and rising cost of credit brought on by the crisis, a strong negative wealth effect on consumption, and a declining construction industry led to a slowdown in economic growth and a rise in unemployment. This is turn, led to lower profits and wages, which triggered rising defaults on both business and household loans, especially residential mortgages. Real- and financial-sector problems were mutually infectious.

Excessive leverage, rising defaults, deteriorating expectations, evaporating liquidity and a destructive interaction between the real and financial sectors drove the downturn. These phenomena are integral components of the KM theory of financial market dynamics but are invisible in the mainstream financial market narrative about why radical deregulation is the best policy.

c) Everyone Acted as if the Theory of Optimal Financial Markets Applied to all Major Financial Products, but it Could not Possibly Apply to the Inherently-Nontransparent Securities at the Center of the Recent Boom and Bust

Financial innovation has proceeded to the point where important financial products such as mortgage-backed securities (MBSs) and collateralized debt 
obligations (CDOs) are so complex and so opaque that they are inherently nontransparent. As such, they cannot be traded on standard competitive financial markets, but are sold instead through negotiation between the originating investment bank and a buyer "over the counter." It has been estimated that half of all securities are privately traded. Nontransparent securities traded privately cannot possibly generate 'optimal' prices as defined in mainstream theory. ${ }^{20}$ For this reason alone, no one should have put any credence in efficient market theory as a guide to regulatory policy.

According to the Securities Industry and Financial Markets Association (SIFMA), there was \$7.4 trillion worth of MBSs outstanding in the first quarter of 2008, more than double the amount outstanding in 2001 . Over $\$ 500$ billion dollars in CDOs were issued in both 2006 and 2007, up from $\$ 157$ billion as recently as 2004 (SIFMA website). The explosion of complex MBSs and derivative products created large profits and bonuses at giant banks and other financial institutions, but also destroyed the transparency necessary for any semblance of market efficiency. Since these securities were nontransparent, so were the institutions that held them.

Exchange-traded securities are sold in highly competitive and transparent markets with low profit margins accruing to the market-making institution. Thus, banks had a strong incentive to create products so complex that they could not be sold on exchanges at all. By the mid-2000s, 80 percent of derivatives were sold over-the-counter in private deals. Such agreements are characterized by oligopoly pricing power, asymmetric information and unequal bargaining power that allow banks to generate high profit margins.

Consider the collateralized debt obligation.A mortgage-backed CDO converts the cash flows from the mortgages in its domain into tranches or slices with different risk characteristics. Several thousand mortgages may go into a single MBS and as many as $150 \mathrm{MBSs}$ can be packaged into a single CDO.

A textbook on credit derivatives explains that:

Even with a mathematical approach to handling correlation, the complexity of calculating the expected default payment, which is what is needed to arrive at a CDO price, grows exponentially with an increasing number of reference assets [the original mortgages].... As it turns out, it is hard to derive a generalized model or formula that handles this complex calculation while still being practical to use (Chacko, Sjoman, Motohashi and Dessain 2006, p. 226).

The risk associated with mortgage-backed CDOs cannot possibly be priced correctly. Ratings agencies and the investment banks that create these securities rely on simulation models to assess their risk, but these models are unreliable and easily manipulated, and these institutions have strong incentives to produce unrealistically high ratings. The models are "black boxes": data is fed in and millions of lines of computer code spit out a rating. It should come 
as no surprise that market operatives referred to the process through which investment banks and ratings agencies priced or marked CDOs as marking to "magic" or to "myth."

The fact that neoclassical financial theory obviously cannot generate its signature optimality conclusion when no one knows the properties of a security somehow never came up in the deregulation debate.

\subsection{CONCLUDING THOUGHTS}

Many factors contributed to the recent financial crisis. Instability is built into capitalist financial markets, a historical fact incorporated in the financial market theories of Keynes, Minsky, Marx and others. ${ }^{21}$ In recent decades, financial innovation, perverse bonus-driven compensation systems, rising leverage and global integration led to reckless financial market expansion and excessive risk-taking that generated a series of dangerous financial crises. Government intervention to shorten and limit the depth of these crises in turn created moral hazard that induced even greater risk-taking that accelerated the long-term financial explosion. Nevertheless, there is no doubt that radical financial market deregulation was a necessary condition for the generation of a secular financial expansion this long and this strong, and for the creation of a global crisis as severe as the one we are still living through.

So many powerful forces demanded deregulation in this period that it might have taken place even if the economics profession had adopted KM theory and spoken out forcefully against it. But had this happened, the deregulation process would have been much more difficult and the current crisis might have been much less destructive. The economics profession does bear some responsibility for the severity of the current crisis and the human suffering associated with it. In this chapter I have argued that the profession's support for deregulation is based on a misleading theory of financial markets constructed on obviously unrealistic assumptions that have very little empirical support. As the world recently observed, predictions based on efficient financial market theory turned out to be catastrophically wrong. To take this theory seriously, one must accept Friedman's positivist methodology because it asserts against logic and common sense, that the realism of assumptions has no bearing on the validity of a theory, and that it is impossible to distinguish between realistic and non-realistic assumptions. Since neither of these propositions is true, economists should accept Keynes's method, which asserts that realistic theories cannot be founded on crudely unrealistic assumptions, and reject all theories of perfect markets. As Harvard's Dani Rodrik put it: "The idea that markets are self-correcting received a mortal blow in the recent financial crisis and should be buried once 
and for all" (Rodrik 2011). Until the profession rejects Friedman's positivism and adopts some variant of the Keynes-Minsky approach to theories of financial markets, policy makers should pay no attention to advice from the economics profession on matters of financial market regulation.

\section{NOTES}

1 As explained below, there is a distinction in theory between financial market efficiency and optimality. In ordinary discourse, the term efficiency often embodies both properties.

2 Government officials also supported deregulation because they received huge campaign contributions from Wall Street. Moreover, politicians and top staff members who supported Wall Street's agenda frequently were rewarded with high-paying lobbyist jobs or employment by large financial institutions.

3 A softer version of Fukuyama's thesis can be found in Epstein and Carrick-Hagenbarth 2010. They argue that many top financial economists had close and highly remunerative ties to Wall Street firms, and this may have affected their public support of radical financial markets deregulation.

4 In this chapter the term positivism refers specifically to Friedman's interpretation of the concept.

5 The theory acknowledges that unforeseen changes in the economy might alter cash flow distributions. However, since agents are assumed to act as if they were positive that the current expected cash-flow distributions were permanent, this is a distinction without a difference.

6 For a critical evaluation of positivism, see Caldwell 1994.

7 This assumption involves a logical contradiction. If agents did assume they knew the future, they could not be rational agents because there is no logical foundation for this belief. See Crotty 1994 for a defense of this assertion.

8 There is the challenge of finding an empirical proxy for the expected covariance of a security. In practice, the past covariance is used as the proxy, which may introduce serious error into the econometric tests. This is an example of the Duhem-Quine problem at work.

9 See Glickman 1994 for a general discussion of this problem.

10 Malkiel's presumption is that professionals can't beat the market because security prices always properly incorporate complete and correct information about future cash-flows. However, if the future is uncertain and unknowable as Keynes insisted, it might still be impossible to beat the market on a consistent basis. Even if pros cannot beat the market, this does not imply markets are efficient.

11 Shiller offered a related criticism. "Individual investors get advice from professional investors, and they can easily observe (albeit with some time lag) what professional investors are doing. So there may be no significant difference between the success of professional investors and the market as a whole, even if their analysis is valuable to others" (2005, p.180).

12 Frydman and Goldberg 2011 (pp. 93-94) note that Fama acknowledged that "in an uncertain world the intrinsic value of a security can never be determined exactly." Thus, rational agents can disagree about appropriate security prices. By "Fama's own account, there is no intrinsic value that competition among intelligent participants could establish." Given uncertainty, Frydman and Goldberg argue, the idea that individuals "can arbitrage away discrepancies between actual prices and intrinsic values has no meaning."

13 Shiller also provided a widely accepted critique of the CAPM by testing whether the behavior of stock price indices is consistent with their assumed determination by the present value of future market profits. He finds that it is not. "Stock price indices are far more volatile than the corporate profits that are assumed to determine their value" (Shiller 2005, p. 185).

14 Perfect knowledge implies perfect transparency. This means all agents have perfect information about financial products, an assumption badly violated in important financial markets in recent years. 
15 Connecting real and financial sectors is a separate task left to macro-economics, but in 'modern' macro theory, the financial sector is usually represented only by an interest rate.

16 In 2008, the annual turnover on the New York Stock Exchange was 138 percent. On average, the entire value of all the firms listed on the exchange was sold 1.4 times in 2009.

17 See Crotty 2010 for an explanation of how perverse compensation incentives in financial institutions contributed to the recent financial crisis.

18 The importance of the "new era" syndrome in the generation of recurrent financial crises is stressed in Reinhart and Rogoff 2009.

19 Taleb states that the assumption that security prices are normally distributed implies that "an episode such as the [1987] crash (more than twenty standard deviations) would take place every several billion lifetimes of the universe" (2007, p. 274).

20 A Financial Times article noted that most of the $\$ 600$ trillion dollars worth of private or overthe-counter derivatives contracts "are rarely if ever traded..." It cited a regulator who said there was one day in 2008 when just two trades in credit default swaps caused worldwide market panic ("Raising the curtain on the private nature of derivatives," September 17, 2010).

21 See Crotty 1985 for defense of the thesis that Marx's theory of financial markets is similar to those of Keynes and Minsky.

\section{REFERENCES}

Amromin, G. and S. Sharpe. 2009. "Expectations of Risk and Return Among Household Investors." Federal Reserve Board of Governors, Finance and Economics Discussion Series, No. 17.

Beaver, W. 1981. "Market Efficiency," The Accounting Review, Vol. LLVI, No. 1, pp. 23-37.

Caldwell, B. 1994. Beyond Positivism. London: Routledge.

Camerer, C. and G. Lowenstein. 2004. "Behavioral Economics: Past, Present, and Future." In C. Camerer, G. Lowenstein and M. Rabin, eds., Advances in Behavioral Economics, pp. 105-47. Princeton: Princeton University Press.

Chacko, G., A. Sjoman, H. Motohashi, and V. Dessain. 2006. Credit Derivatives Philadelphia: Wharton School.

Crotty, J. 1985. "The Centrality of Money, Credit and Financial Intermediation in Marx's Crisis Theory." In S. Resnick and R. Wolff, eds., Rethinking Marxism: Essays in Honor of Harry Magdoff and Paul Sweezy. New York: Autonomedia, pp. 45-82.

Crotty, J. 1994. "Are Keynesian Uncertainty and Macrotheory Incompatible? Conventional Decision Making, Institutional Structures and Conditional Stability in Keynesian Macromodels.” In G. Dymski and R. Pollin, eds., New Perspectives in Monetary Macroeconomics: Explorations in the Tradition of Hyman Minsky. Ann Arbor: Univ. of Michigan Press, pp. 105-142.

Crotty, J. 2009. "Structural Causes of the Global Financial Crisis: A Critical Assessment of the 'New Financial Architecture'," Cambridge Journal of Economics, July 2009, Vol. 33, No. 4, pp. 563-80.

Crotty, J. 2010. "The Bonus-Driven "Rainmaker Financial Firms: How These Firms Enrich Top Employees, Destroy Shareholder Value and Create Systemic Financial Instability," Political Economy Research Institute, University of Massachusetts, Amherst, Working Paper 209. Available at: http://www.peri.umass.edu/fileadmin/ pdf/working_papers/working_papers_201-250/WP209_revised2.pdf

Epstein, G. and J. Carrick-Hagenbarth. 2010. "Financial Economists, Financial In- 
terests and Dark Corners of the Meltdown: It's Time to Set Ethical Standards for the Economics Profession," Political Economy Research Institute Working Paper Series, No. 239, Nov. Available at: http://www.peri.umass.edu/fileadmin/pdf/working_papers/working_papers_201-250/WP239_revised.pdf.

Fama, E. 1991. "Efficient Capital Markets: II," The Journal of Finance, Vol. 46, No. 5, pp. 1575-1617, December.

Fama, E. and K. French. 2004. "The CAPM: Theory and Evidence," Journal of Economic Perspectives, Vol. 18, No. 3, pp. 25-46, Summer.

Federal Reserve Bank of Minneapolis. 2007. "Interview with Eugene Fama," The Region, December.

Findley, M. and E. Williams. 1985. "A Post Keynesian View of Modern Financial Economics: In Search of Alternative Paradigms," Journal of Business and Finance, Vol. 12 , No. 1, Spring.

Findley, M. and E. Williams. 2008-09. "Financial economics at 50: an oxymoronic tautology," Journal of Post Keynesian Economics, Vol. 31, No. 2, pp. 213-26, Winter.

Friedman, M. 1953. Essays in Positive Economics. Chicago: University of Chicago Press.

Frydman, R. and M. Goldberg. 2011. Beyond Mechanical Markets. Princeton University Press.

Glickman, M. 1994. The concept of information, intractable uncertainty, and the current state of the "efficient" markets theory: a Post Keynesian view," Journal of Post Keynesian Economics, Vol. 16, No. 3, pp. 325-49, Spring.

Keynes, J. M. 1937. "The General Theory of Employment," Quarterly Journal of Economics, Vol. 51, pp. 209-223.

Keynes, J. M. 1973. The General Theory of Employment, Interest and Money. London: Macmillan.

Lawson, T. 1985. "Uncertainty and Economic Analysis," The Economic Journal, Vol. 95, No. 380, pp. 909-27, December.

Malkiel, B. 2003. "The Efficient Market Hypothesis and Its Critics," Princeton University Center For Economic Policy Studies, Working Paper No 91, pp. 1-47, April.

Malkiel, B. 2005. "Reflections on the Efficient Market Hypothesis: 30 Years Later," The Financial Review, Vol. 40, pp. 1-9.

Mehrling, P. 2005. Fischer Black and the Revolutionary Idea of Finance. Hoboken, New Jersey: John Wiley and Sons, Inc.

Rabin, M. 2002. "A Perspective on Psychology and Economics," European Economics Review, 46,pp. 657-685.

Reinhart, C. and K. Rogoff. 2009. This Time is Different: Eight Centuries of Financial Folly. Princeton: Princeton University Press.

Rodrik, D. 2011. "New Rules for the Global Economy," http://www.project-syndicate. org/commentary/rodrik52/English.

Securities Industry and Financial Markets Association. Available at: http://www.sifma. org/about/.

Sharpe, W. 1964. "Capital Asset Prices: A Theory of Market Equilibrium under Conditions of Risk," The Journal of Finance, Vol. 19, Issue 3, pp. 425-442, September.

Shackle, G. L. S. 1992. Epistemics and Economics. London: Transactions Publishers.

Shiller, R. 1992. Market Volatility. Boston: MIT Press.

Shiller, R. 2005. Irrational Exuberance. New York: Broadway Books.

Skomarovsky, M. 2011. "Evidence of an American Plutocracy: The Larry Summers Story," Truthout, January 10, 2011. Available at: http://www.truth-out.org/evidenceamerican-plutocracy-the-larry-summers-story67007.

Smith, Y. 2010. Econned. New York: Palgrave Macmillan. 
Solow, R. 1988. "Growth Theory and After," American Economic Review, Vol. 78, pp. 307-17.

Summers, L. 1985. “On Economics and Finance," Journal of Finance, Vol. 40, No. 3 , pp. 633-35, July.

Taleb, N. 2007. The Black Swan: The Theory of the Highly Improbable. New York: Random House. 